\title{
correspondence
}

\section{Western attitude in jeopardy}

SIR,-I understand Ziauddin Sardar's frustration (18 May, page 176), but I feel that his views could be damaging in many ways, in particular to the slowly-changing attitude in the West that there is a need for more appropriate development aid. The battle which is bringing about this change in attitude has been fought for many years and in the UK it looks as though it is slowly being won. For example, the UK Ministry of Overseas Development's 1975 White Paper 'More help for the poorest', which set out the case for better aid programmes, is having a positive effect in the West.

Sardar may feel that change is too slow, that it is still muddle-headed and far from appropriate. I would agrce with him. But it is up to developing countries themselves to choose the good from the mediocre and to insist on their rights. If they choose to cut themselves off completely they will lose the support which is building up in the West, they will isolate those who have bcen campaigning for change in Europe and the United States and they will ultimately hold up their own progress.

Not that I think they will. The real answer is not the extreme that Sardar proposes and I am sure many scientists would prefer a middle course. Those in the countries of which I have some knowledge, Vietnam, Mozambique and Tanzania, do want contact with western scientists; and I also know of Egyptian scientists who feel the same.

Alastair $\mathrm{H}_{\text {Ay }}$

University of Leeds, UK

\section{Lead levels in Birmingham}

SiR, - The generally reassuring tenor of Judy Redfearn's article (8 June, page 417), based on the HMSO pollution paper no. 14, largely stems from misleading presentations of three salient aspects of the issue.

Ms Redfearn is wrong to state that there was no significant increase in blood lead levels of people living near the M6-A38 (M) interchangc. The HMSO publication quite clearly reports (table 48) an increase of $29^{\circ} \prime$ for adult males and 26 "' for adult females in a group, living $200 \mathrm{~m}$ from the centre of the interchange, for whom all confounding factors can bc eliminated.

The claim that none of the seven pre-school children with blood lead levels greater than $35 \mu \mathrm{g}$ " "showed any significant psychological disturbance" is not based on an appropriate assessment and can in no way be coupled with the German, Canadian and American studies which are mentioned later in the article.

The misleading implication that tooth lead levels measured by expert analysts can give results that vary as widely as those found by the inexpert for concentrations of lead in blood is inexcusable; more especially so when no recognition is made of the fact that there is an important analytical advantage afforded by the approximately one hundred-fold higher concentration of lead in a tooth than in its blood-supply.

Instead of portraying the interchange with the legend "Spaghetti junction: clcan bill of health", perhaps a better perspective would be provided by setting the mean blood lead concentrations for males $\left(28.8 \mu \mathrm{g}^{\circ},\right)$ and females $\left(23.2 \mu \mathrm{g}^{\prime \prime}\right.$, ) (table 49, HMSO pollution paper no. 14) living nearby against the inatural blood lead level of $0.25 \mu \mathrm{g} \stackrel{\circ}{\circ}$ calculated by Patterson in 1965 .

\section{R. STEPHENS}

University of Birmingham, UK

\section{Saccharin: the risks and benefits}

SlR,-I am writing in reply to the letter by A. B. Miller and G. R. Howe (4 May, page 8) objecting to my paper on "Saccharin: the risks and benefits" (9 February, page 492). The estimate of 1,200 extra bladler cancers per year if each US citizen were to ingest one diet drink per day was not mine; it was given by the US Food and Drug Administration as the basis for their policy of attempting to ban saccharin. My paper simply accepted their estimate of the risk, compared it with the risk of ingesting an equivalent amount of sugar, and showed that the latter risk was 100 times greater for a person who is as much as $10 \%$ overweight.

Since the average American is about $12 "$ " overweight (Metropolitan Life Ins. Co. Stat. Bul. January 1977), it would seem to be highly beneficial to the public if the food processing industry were to substitute saccharin for sugar. The point that Miller and Howe miss is that sugar is also "a potentially hazardous substance", much more hazardous than saccharin even by their estimates.

Bernard L. Cohen University of Pittsburgh, USA

\section{Burying high level wastes}

SIR,- R. M. Macintyre (Burying high-level wastes, 16 February, page 605 ), states that geochronologic $\mathrm{K}-\mathrm{Ar}$ data argue against the suitability of bedded salt deposits fo: the burial of high-level waste. It is disturbing to see such generalisations made with data which are improperly interpreted.

It is well-recognised that sulvites (KC1) vield low $\mathrm{K}-\mathrm{Ar}$ dates. The reason for radiogenic ${ }^{40} \mathrm{Ar}$ loss from cvaporite minerals may be dissolution (as Macintyre proposes) or diffusion (Dalrymple and Lanphere, Potassium-Argon Dating. W. H. Freeman and Company, San Francisco, 1969). Not considered in Macintyre's correspondence arc the following data:

- some sylvites do vield $\mathrm{K}-\mathrm{Ca}$ ages consistent with their age of formation
(Polevaya et al., Geochemistry, 8, $897-906,1958$ ), thus demonstrating that while an inert gas such as "Ar can be lost from sylvite, a solid species like radiogenic ${ }^{40} \mathrm{Ca}$ is retained in the sylvite structure.

- $\mathrm{K}$-Ar studies of various K-bearing minerals from the Los Medanos area near Carlsbad, New Mexico

(Isochron/West, 6, 37, 1973) show that sylvites yield anomalously low dates of $18+8$ to $74 \pm 8$ my. A langbeinite yields $245 \pm 10 \mathrm{my}$, a date corresponding to the late Permian (the time of deposition). Two samples of mixed sylvite-langbeinite yield $137 \pm 8 \mathrm{my}$ and $147 \pm 10 \mathrm{my}$. Certainly all three dates for langbeinite and langbeinite-sylvite argue against "recent" recrystallisation in thesc deposits.

In support of the Waste Isolation Pilot Plant project, the Los Medanos area of south-eastern New Mexico (USA) is being subjected to intensive study including geochronology to assess the stability of the bedded evaporites since the Late Permian. Fluid inclusions studies of Roedder have identified nonrecrystallised Los Medlanos salt. Certainly there are no data to substantiate ". . percolating groundwaters ....". Salt diapirism in subhorizontal salt beds $700 \mathrm{~m}$ deep, such as at Los Medanos, has adequately been discussed by Gera (Geological Society of America Bulletin, 83, $3551-3574,1972$ )

First results of an ongoing $\mathrm{Rb}-\mathrm{Sr}$ geochronological study conducted by Brookins and others show that a $\mathrm{Rb}-\mathrm{Sr}$ isochron based on water-soluble fractions of evaporite minerals and authigenic clay minerals yields a date of $204 \mathrm{mv}$ with an initial ${ }^{87} \mathrm{Sr} /{ }^{86} \mathrm{Sr}$ of 0.7137 . This data is interpreted as a minimum since independent data from Ca-rich phases indicate an initial ${ }^{87} \mathrm{Sr} /{ }^{86} \mathrm{Sr}$ ratio of $0.7081 \pm 0.0007$

Polvhalitc and sylvite, properly identified as recrystallisation products, must have formed early in the diagenetic history of the evaporites. else the Rh-Sr dates for such samples would be characterised by very young dates and probably much higher initial ${ }^{87} \mathrm{Sr} /{ }^{86} \mathrm{Sr}$ ratios.

Finally, it is unreasonable to assume that the escape behaviour of argon should be representative of all radiogenic daughter products. Strontium, which is also an important mobile constitutent of radioactive waste, has certainly been retained in the evaporites for $2 \times 10^{k}$ ycars. The impurities such as trioctahedral clavs in Los Medanos rock salt have also been found to preferentially absorb from aqueous solution actinides present in waste.

D. G. BROOKINS

J. K. RFGISIER

M. E. REgISTFR

University of New Mexico.

Albuquerque, USA

S. J. LAMBERT

Sandia Laboratories, Albuquerque,

New Mexico, USA 